\title{
Consultant-Client relationships
}

\author{
R. G. J. Mackintosh
}

Corporations in South Africa are increasingly making use of specialist consultancy services - to help to solve problems concerning personnel, management, financial control, information systems, and so on. Company management is clearly concerned with making the best use of this expensive resource. This involves choosing the right consultancy style for the specific problem at hand, and ensuring that the type of consultant-intervention matches the stage of the organization's life-cycle. A synthesis of some related studies indicated the distinct possibility or a correlation between the stage in the organization's life-cycle, the dominant problem the organization experiences, and the major form of intervention which would be required to resolve the problem. There is a need for empirical work on, and practical application of this approach, which could lead to useful insight in the interests of more effective consultation.

S. Afr. J. Bus. Mgmt 1979, 10: 47-51

Maatskappye in Suid-Afrika maak toenemend gebruik van die konsultantdienste van spesialiste om probleme met betrekking tot personeel, algemene bestuur, finansiële beheer, inligtingstelsels en so meer, te help oplos. Die maatskappybestuur is duidelik besorg daaroor dat hulle die beste gebruik van hierdie duur hulpbron moet maak. Dit beteken dat die regte konsultasie-styl vir die spesifieke probleem wat ondersoek word, gekies moet word. Die tipe konsultasie-tussentrede moet ook pas by die stadium van sy lewensiklus waarin die onderneming hom bevind. 'n Sintese van 'n aantal verwante studies dui die besliste muontlikheid aan van 'n korrelasie tussen die stadium in 'n organisasie se lewensiklus, die dominante probleme wat die onderneming ondervind, en die belangrikste vorm van konsultasietussentrede wat benodig sou word om die besondere probleem op te los. Daar bestaan 'n behoefte aan empiriese werk oor en praktiese toepassing van hierdie benadering wat nuttige insig kan gee in belang van meer doeltreffende konsultasie.

S. Afr. Tydskr. Bedrytsl. 1979, 10: 47-51
The purpose of this paper is to attempt to develop a framework which may be used by the consultant to come to grips with the overall complexity of the consultant-client relationship; and to indicate the areas of empirical research required to assess adequately the likelihood that

- there is a close correlation between an organization's 'ideology', its 'style' (or 'personality') and its stage of development

- certain types of problems in an organization have a high correlation to the organization's stage of development (and hence also its ideology or personality)

- a certain consultancy approach would be more appropriate to the different stages in the organization's development (likewise its ideology or personality)

- if different broad approaches are necessary at different stages in the development of the organization, then the relationship or 'contract' between consultant and client, and the way it is likely to develop, can be assessed more accurately by the consultant at the outset of the study.

The implications are that the consultant should know his own style of working before accepting an assignment with a client; and that the consultant should direct the work into the most suitable method of operating, handing over the case to another consultant with a more appropriate style if necessary.

\section{The consultant's own style}

A number of factors can cloud the consultant's objectivity in his analysis of the problem(s) facing the organization.

Firstly, his training and methodology may cause the consultant to begin the case with certain assumptions, or from a specific viewpoint which may or may not be relevant to the client.

Secondly, the consultant's own personality and style will predispose him to certain modes of intervention:

- acceptant (provides an environment where client is free to express thoughts and feelings)

- catalytic (assists client in collecting data and information to re-interpret perceptions)

- confrontation (challenges a client to examine his present foundations of thinking) 


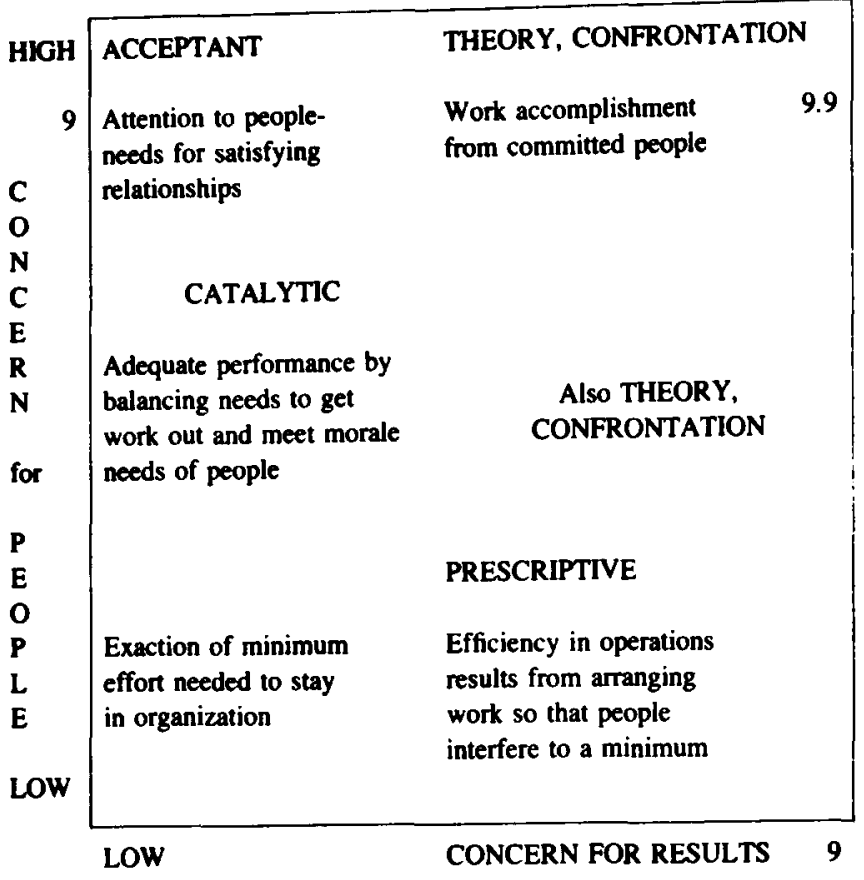

Fig. 1 Managerial Grid

- theory and principles (offers theories and principles pertinent to client's situation to help the client internalize systematically implicitly tested ways of understanding)

- perscriptive (direct instruction concerning course of action client should follow).

The above 'Managerial Grid' shows how different levels of concern for people and results would bring about different styles of consultant intervention. For example, if the consultant is primarily result-centred, his approach will tend towards being perscriptive - specifying set solutions to the perceived problems.

An awareness of his particular style should help the consultant to be more sensitive to other approaches to solving problems, and more sensitive to the needs of the client.

\section{Organizational ideologies}

Groups engage in what they regard as normal and appropriate practice. In the same way, members of organizations may be adherents of a self-consistent and internally logical way of thinking and explaining their organizational world.

Roger Harrison ${ }^{2}$ outlines the functions that an organizational ideology performs:

- specifies goals and values

- depicts which qualities and characteristics of the organization's members should be valued or vilified

- indicates how behaviour within the organization should be controlled and what kinds of control are 'legitimate'

- shows members how they should treat one another

- establishes appropriate methods of dealing with the outside environment.

Harrison defines four types of organizational ideology:

Power orientation - in which the organization attempts to dominate the environment.

Role orientation - the organization aspires to be as systematic and rational as possible;

\begin{tabular}{l|l|l|l|l}
\hline $\begin{array}{l}\text { Organizational } \\
\text { ideologies }\end{array}$ & $\begin{array}{l}\text { Power } \\
\text { orientation }\end{array}$ & $\begin{array}{l}\text { Role } \\
\text { orientation }\end{array}$ & $\begin{array}{l}\text { Person } \\
\text { orientation }\end{array}$ & $\begin{array}{l}\text { Task } \\
\text { orientation }\end{array}$ \\
\hline $\begin{array}{l}\text { Found in: } \\
\text { phases of } \\
\text { organization } \\
\text { growth }\end{array}$ & Pioneer & Differentiation & Integration \\
\hline $\begin{array}{l}\text { Characterized by: } \\
\text { size of } \\
\text { organization }\end{array}$ & Small & $\begin{array}{l}\text { Functional, } \\
\text { specialization }\end{array}$ & & $\begin{array}{l}\text { Large, } \\
\text { diversed }\end{array}$ \\
\hline
\end{tabular}

Flg. 2 Juxtaposition of the approaches by Scott and Harrison.

substitutes competitiveness and conflict for consensus, rules and procedures.

Task orientation - the achievement of a super-ordinate goal is the highest value.

Person orientation - the organization exists primarily to serve the needs of members.

Each orientation has an impact on how decisions are made, how human resources are used, and how the environment is approached.

Are these ideologies linked to a particular stage in the organization's growth?

\section{Stages in organizational growth}

Bruce R. Scott ${ }^{3}$ identifies three phases in this growth:

Pioneer phase - characterized by a one-man authority system; highly autocratic, a hub and wheel type reporting and authority structure.

Differentiation phase characterized by specialization, delegation, a formal organization structure, systematization, committees.

Integrated phase - characterized by teamwork, adaptability to new situations, decentralization of control and authority.

It would seem reasonable to assume that the different ideologies, if exhibited at different stages of the life of the organization, should stem from organizational characteristics which resemble those of the dominant-decisionmakers in the organization.

The small firm, in its pioneer phase, would be expected to show aggressive competitiveness in its struggle to survive and grow. A more mature organization, beyond the survival stage, becomes increasingly interested in internal issues, job and role definition, conflict-resolution, internal structures, systems, and functions. The people-needs move to the fore.

Colin Sheppard ${ }^{5}$ distinguishes between three major personality types found within the organization:

- 'tough battler'

- 'friendly helper'

- 'objective thinker'

These descriptions can be used equally to depict the predominant way in which an organization behaves within its environment, and towards its own members. 


\begin{tabular}{l|l|l|l}
\hline \multirow{2}{*}{$\begin{array}{l}\text { Organizational personality } \\
\begin{array}{l}\text { leads to an } \\
\text { Organizational ideology }\end{array}\end{array}$} & $\begin{array}{l}\text { Tough } \\
\text { battler }\end{array}$ & $\begin{array}{l}\text { Friendly } \\
\text { helper }\end{array}$ & $\begin{array}{l}\text { Objective } \\
\text { thinker }\end{array}$ \\
\cline { 2 - 4 } & $\begin{array}{l}\text { Power } \\
\text { orientation }\end{array}$ & $\begin{array}{l}\text { Role/Person } \\
\text { orientation }\end{array}$ & $\begin{array}{l}\text { Task } \\
\text { orientation }\end{array}$ \\
\hline
\end{tabular}

Fig. 3 Interrelationships between the organization's personality and its manifest ideology.

We would therefore expect the 'tough battler' to occur both as a real life personality, and as an organizational style within small, pioneer organizations. Power-orientation, the drive to dominate, control and compete, the appetite for growth, can be reasonably expected to reflect the early stages of an organization's development.

As the organization grows into a large diversified group (the 'divisional structure'), a strong emphasis is placed on strategic corporate issues, for example: What is our business? What customer needs can we identify, and which should we satisfy?

Objective, analytical thinking and research become necessary. The organizational structure and functions come to be evaluated in objective strategic terms. The emphasis shifts strongly towards structures which can offer rapid response to environmental and technological change. Great stress is laid upon small, aggressive task-force (matrixorganization) structures in an attempt to recapture the successful 'pioneer phase'. Ideological commitment to authority diminishes.

\section{Impact on the management learning processes}

The ability to adapt and learn is necessary for the organization to move successfully into and through different growthphases.

According to $\mathrm{Kolb}^{6}$ (the individual or the organization) needs four different kinds of abilities for effective learning:

- concrete experience

- reflective observation

- abstract conceptualization

- active experimentation

Here again, it seems likely that as organizations develop, some of these learning abilities will dominate at the expense of others as seen in Fig. 4.

While a case could be made for these shifts in emphasis, leading to imbalances to be present at each phase, the organization must continually choose which set of learning abilities it needs in each situation. Failure to do so frequently means either that the organization is failing to learn from past experience, or that it is not seeking enough experiences to grow in its competitive environment. Organizational 'stress' develops if the imbalance continues indefinitely - and finally failure in the market results in drastic and traumatic reorganization, internal conflicts and status changes, and perhaps liquidation of the enterprise.

\section{Are different types of problems common to different stages of organizational development?}

The main hypothesis here is that just as a person will have different problems in pre-teen, adolescent and adult stages

\begin{tabular}{|c|c|c|c|}
\hline $\begin{array}{l}\text { Phase of organi- } \\
\text { zational development }\end{array}$ & Pioneer & Differentiation & Integration \\
\hline
\end{tabular}

Fig. 4 Dominating learning abilities.

of life, so too the organization can expect different types of problems in its Pioneer, Differentiation and Integration phases.

But just as, say, adolescents have similar but not identical problems to one another, we can expect organizational problems to be similar but not identical.

If the analysis is correct, we should, however, expect at least one major distinction between these two examples. Whereas the adolescent's problems are associated with his stage of growth, personality usually remains reasonably intact throughout his life.

This might not be true of all organizations, whose 'personalities' may be expected to change radically with the life-cycle. (However, organizations such as General Motors, which have spent perhaps decades in the same growthcategory, can be expected to exhibit the same 'personality' over long periods of time.)

Blake and Mouton ${ }^{1}$ identify four focal-issue categories facing the client:

- power/authority

- morale/cohesion

- standards/norms

- goods/objectives.

While the authors stress that these categories are interdependent (if not immediately, certainly over time), the focal issue is that aspect of a situation presently causing the client difficulty.

This stresses even more heavily the necessity for the consultant to be aware of the complexity of the organization as a system internally and over time.

The authors further stress that the kind of intervention employed - acceptant, catalytic, confrontation, prescriptive, theory/principles - may also be dictated by the focal-issue.

\section{Focal issues}

\section{Power/Authority}

How people react to power/authority can be a factor in increasing or decreasing their effectiveness. Attitudes to authority and people in authority are shaped by several factors - personal values, culture, and tradition. Different types of authority, for example, hierarchical, sapiental, and charismatic, may also be important at different stages of the organization's growth. (For example, sapiental authority receives a higher weighting in research-dependent situations.)

What kind of intervention would be most suitable? Firstly, it is unlikely that either perscriptive or confrontation-intervention would have much success. Too much depends on the initial acceptance of the intervention.

Developing an understanding of theory and principles or organizational behaviour and motivation with the client would appear relevant, coupled with catalytic and acceptantinterventions. 


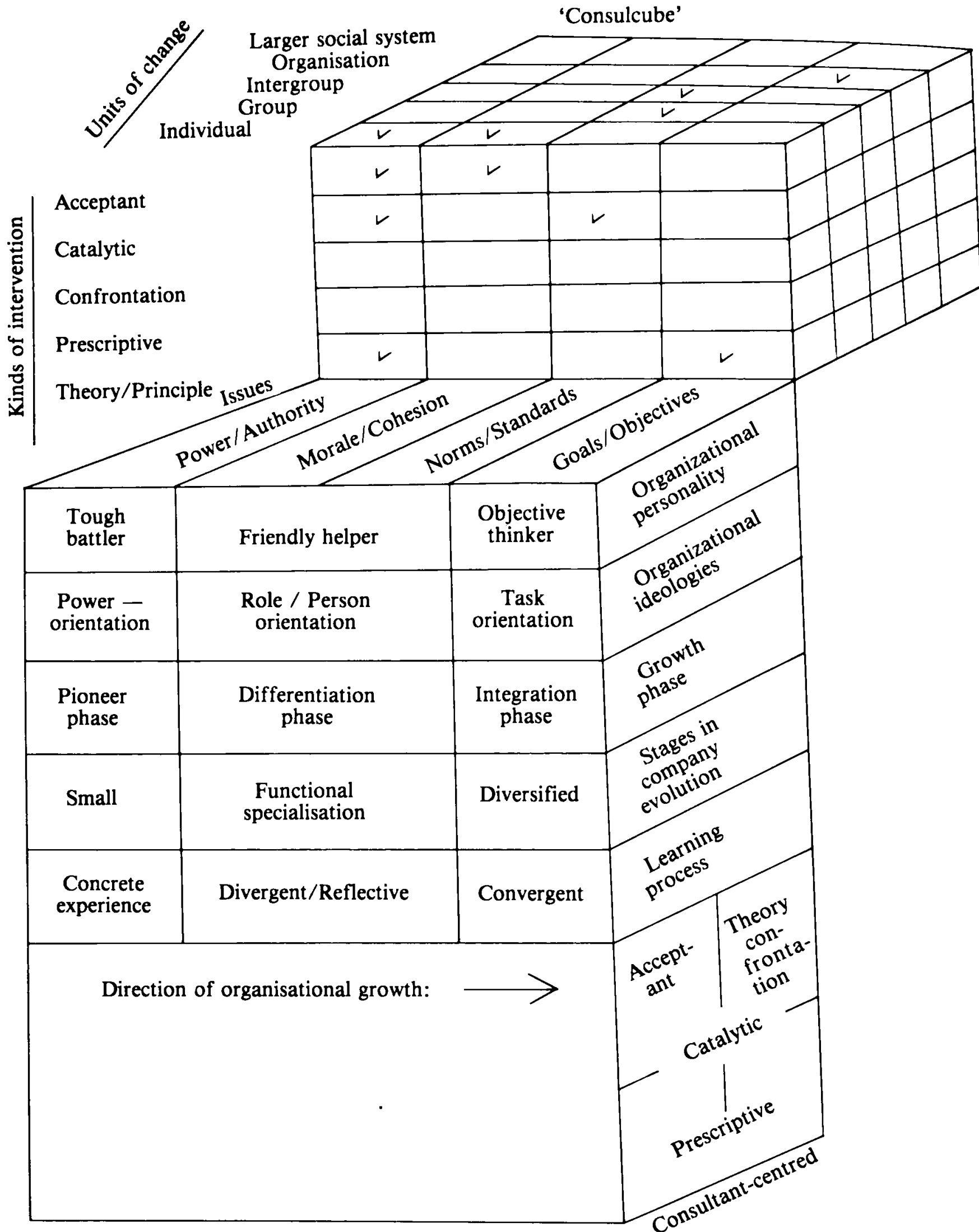

SOURCE: 'Consulcube' from Blake \& Mouton, Ref 1. Total model developed by author to show up interrelationships between other theories discussed in this paper.

Fig. 5 A framework for the consultant-client relationship.

Morale/Cohesion

Feelings and emotions associated with a sense of well-being or despair, when uncorrelated with objective circumstances, can lead to irrational behaviour. Such behaviour can arise from loss of identity, self-rejection and personal disintegration.

Empirical research would be necessary to thoroughly test this correlation with an organizational phase. 
Despair can arise through organization trauma - critical events which cause members to lose their normally strong sense of commitment to the organization. This can occur as a result of an organizational shake-out following a reorganization, the appointment of a new chief executive perhaps as the company makes a rapid transition from pioneer to differentiation phases, or from a functional structure to a divisionalized structure.

Suitable interventions would be directed towards helping the client 'mourn' the past, then accept the challenges of the future. Acceptant-intervention would be the most suitable.

\section{Norms/Standards}

Norms are central to the identity and functioning of groups. They are frequently resistant to change and are reinforced by emotions towards the group. To develop, they require that membership of the group remains relatively stable, and that primary commitment is to the group and not to the task.

Intergroup problems may arise for this reason. These should arise more frequently in an organization with an overtly person-oriented ideology.

A successful intervention results in the group(s) formulating new norms, with a commitment to them. The consultant should be most successful as a catalyst 'outsider' to the group(s) and therefore with no axe to grind.

\section{Goals/Objectives}

These give character and direction to the organization's enterprise. But goals may be expressed in too-abstract terms to be of much use in setting direction and measuring performance results.

Classifying organizational goals may become an especially vital exercise as the enterprise enters a new phase in its development. Strategic corporate issues are particularly pressing as a company contemplates diversification and divisionalized structures. Task-orientation may provide such high group membership turnover that the task supercedes the group norm: low group cohesion, high taskcommitment.

Perhaps the only suitable intervention by the consultant is the provision of adequate theory and principles to aid the client in:

- goal classification

- goal redefinition

- restructuring activities

- goal setting.

By contrast, prescriptive interventions impose the consultant's will on the client. To stand a chance of acceptance, such interventions firstly need very accurate diagnosis of the problem. The model in Fig. 5 integrates the different concepts discussed above as they relate to different aspects of consultant-client relationships and to characteristics and stages in the organizational life cycle.

\section{Conclusion}

The article outlined the potential and need for a broadlybased research effort to test the hypothesis that different interventions are necessary to deal with specific problems existing in each phase of the organization's growth.

There has been no empirical work done directly on this question. However, a synthesis of some related studies indicates a theoretical possibility that there is a correlation between the stage in the organization's life-cycle, the dominant problems it has, and the major form of consultantintervention which would be required to resolve the problems of each particular organization.

\section{References}

I BLAKE, ROBERT R. \& MOUTON, J. 1976. Consultation. (Addison Wesley).

2 HARRISON, ROGER 1975. Understanding your Organization's Character. Unpubl. paper - School of Management. Cranfield Institute of Technology, UK.

3 SCOTT, BRUCE R. 1973. The Industrial State: Old Myths and New Realities. Harv. Bus. Rev. March, p. 133.

4 HARRISON, KEN 1973. Phases in Organizational Growth. Unpubl, paper, School of Management, Cranfield Institute of Technology, UK.

5 SHEPPARD, COLIN 1973. Emotional Problems in Groups and Organizations. Unpubl. paper - School of Management, Cranfield Institute of Technology, UK.

6 KOLB, DAVID A. 1975. On Management and the Learning Process. In: Organizational Psychology: A Book of Readings, Second Edition, p. 27. 